\title{
The effectiveness of Celosia argentia (Striga "chaser") to control Striga on Sorghum in Uganda
}

\author{
J.R. Olupot ${ }^{\mathrm{a}, *}$, D.S.O. Osiru ${ }^{\mathrm{a}}$, J. Oryokot ${ }^{\mathrm{b}}$, B. Gebrekidan ${ }^{\mathrm{c}}$

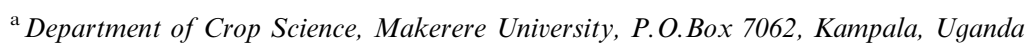 \\ ${ }^{\mathrm{b}}$ Serere Agricultural and Animal Production Research Institute, Soroti, Uganda \\ ${ }^{\mathrm{c}} I P M$ CRSP, Virginia Tech., Blacksburg, VA, USA
}

Received 18 June 2002; received in revised form 28 August 2002; accepted 31 August 2002

\begin{abstract}
Field, screen house and laboratory studies were carried out to assess the capacity of Celosia argentia to control Striga on sorghum in Uganda. The field experiment was aimed at determining the effectiveness of inter-planting Celosia argentia into sorghum in the suppression of Striga and increasing sorghum yield. The screen house experiment looked at the optimum proportion of $C$. argentia to be inter-planted into sorghum to effectively suppress Striga and maintain a good sorghum yield. The laboratory study was to quantify the capacity for $C$. argentia to effect Striga seed germination.

Inter-planting $C$. argentia into sorghum reduced Striga emergence by an average of $55 \%$ in a season and increased the yield of a susceptible sorghum variety in the field by $35 \%$ compared to the sole sorghum treatment. Results of the screen house experiment showed that inter-planting $C$. argentia into sorghum at a ratio of 2:1 suppressed Striga best by as much as $48 \%$ and resulted in the highest yield increase $(100 \%)$ compared to the sole sorghum treatment. The laboratory study showed that $C$. argentia could induce suicidal germination in Striga seed by as much as $68 \%$ compared to cotton which was taken to be the standard.
\end{abstract}

(C) 2003 Elsevier Science Ltd. All rights reserved.

Keywords: Celosia argentia; Striga; Sorghum bicolor

\section{Introduction}

Witchweeds (Striga spp.) are root hemi-parasites which cause significant loses to food crops in Asia and Africa. In Africa, up to 45 million ha of arable land is threatened by these weeds (Sauerborn, 1991). In Uganda, there are two species of economic importance; Striga hermonthica and Striga asiatica. The former, which is the most widely distributed Striga species in Uganda, severely affects sorghum yield, the third most important cereal crop in the country. Yield loses at individual farms are estimated at $60-100 \%$ (Anonymous, 1997). Small-scale farmers are the most severely affected by Striga because they have limited ways and means of controlling it. Current farming practices including; intensive cultivation of small pieces of land with shortened or no fallow (Webb et al., 1993) and continuous cereal cropping have led to a rapid decline

\footnotetext{
*Corresponding author.
}

in soil fertility and a build up of Striga seed in the soil seed bank.

Effective and economically affordable means of Striga management for small-scale farmers are not presently available in Uganda. During a survey conducted by the National Agricultural Research Organisation (NARO) in 1997, to quantify the Striga problem in eastern Uganda, farmers pointed out an age old practice of inter-planting a Striga "Chaser" into sorghum for the control of Striga (Anonymous, 1997). This plant was correctly identified at the Department of Botany herbarium in Makerere University as Celosia argentia (Amaranthaceae).

No comprehensive study has been conducted to determine the effectiveness of $C$. argentia in suppressing Striga. In experiments done in Nigeria however, Celosia argentia was found to suppress weeds more than weeding twice when inter-planted into chewing cane (Busari et al., 1997). In sorghum, the mechanism by which $C$. argentia affects Striga infestation is not known but is hypothesised to be through stimulation of Striga 
seed germination. The objectives of this study were therefore: (a) to evaluate the effect of inter-planting C. argentia into sorghum in the suppression of Striga infestation, (b) determine the optimum proportion of C. argentia to be inter-planted into sorghum to effectively reduce Striga infestation while maintaining increased sorghum yield and (c) to find out the effect of C. argentia on Striga seed germination.

\section{Materials and methods}

\subsection{Field experiment: the effect of inter-planting C. argentia into sorghum on Striga emergence and sorghum growth and yield}

The objective of this experiment was to evaluate the effect of $C$. argentia in suppressing Striga and increasing sorghum yield in the field. An established trap crop, cowpea was used as a basis of comparison. The land was ploughed twice using an ox-plough. Plots measuring $5.6 \mathrm{~m} \times 5 \mathrm{~m}$ were marked out. Three treatments were applied as follows:

(i) Cowpea inter-planted into sorghum.

(ii) Celosia argentia inter-planted into sorghum.

(iii) Sorghum planted alone (control).

Sorghum was spaced at $60 \mathrm{~cm}$ between rows and $20 \mathrm{~cm}$ between plants. Cowpea and $C$. argentia were planted in between the sorghum rows in equal proportion to the sorghum crop giving a 1:1 inter-crop: sorghum ratio. Thinning was done 2 weeks after crop emergence leaving two plants per hole. The experiment was weeded twice, at 2 weeks and 4 weeks after crop emergence. The experimental design was a randomised complete block. This experiment was conducted for three seasons (first rains 1999, second rains 1999 and first rains 2000). In the first rains of 1999, the experiment was replicated five times in one farmer's field while in the second rains, 1999 and first rains, 2000, the experiment was replicated twice in each of the five farmers' fields totalling to ten replications in order to acquire more reliable Striga emergence data. Data were collected on Striga emergence, sorghum growth parameters (days to $50 \%$ flowering and plant height), number of harvestable heads per plot and grain yield.

\subsection{Screen house experiment: to determine an appropriate $C$. argentialsorghum interplanting ratio, which can effectively suppress Striga and maintain increased sorghum yield}

A pot experiment was established in the screen house to determine an appropriate $C$. argentia/sorghum interplanting ratio, which can effectively suppress Striga and maintain increased sorghum yield. The pots measured $23 \mathrm{~cm}$ diameter at the top and $30 \mathrm{~cm}$ heigh.

Filter papers were placed at the bottoms of 36 perforated plastic pots in order to avoid loss of Striga seeds through drainage. Each pot was filled with sandy loam soil collected from Serere Agricultural and Animal production Research Institute $\left(33^{\circ} 27^{\prime} \mathrm{E} 1^{\circ} 31^{\prime} \mathrm{N} ; 100 \mathrm{~m}\right.$ above sea level) (Department of Lands and Survey, 1967).

Eighteen (18) of the pots were infested with $0.2 \mathrm{~g}$ of 8 months old Striga hermonthica seeds collected from Kumi district in eastern Uganda. The Striga seeds were collected on sorghum hosts in farmers' fields. The Striga seeds were placed $8 \mathrm{~cm}$ below the surface of the soil. The other 18 pots were left un-infested. The pots were watered on the first day of infestation and then later after 4 days in order to condition the Striga seeds. After 7 days, C. argentia and sorghum were planted in all the thirty six pots. Each pot was provided with $0.25 \mathrm{~g}$ of NPK fertilizer and watered. Two weeks after emergence, the plants were thinned leaving the following $C$. argentia : sorghum inter-planting ratios, which were to be tested: 1:1, 1:2, 1:3, 2:1, 3:1, 0:1 (sole sorghum).

The experiment was arranged in a completely randomised design and replicated three times. Watering was done after every 2 days until the end of the experiment. Weeds were controlled by hand removal. Data were collected on Striga emergence per pot, sorghum flowering, sorghum plant height at flowering, sorghum shoot dry matter per plant and sorghum grain yield.

\subsection{Laboratory experiment: to determine the influence of C. argentia on Striga seed germination}

In this experiment, $C$. argentia was compared with known Striga germination stimulants i.e. cotton, cowpea, Seredo an improved sorghum variety tolerant to Striga and Inoke a Striga susceptible local sorghum variety. The effect of $C$. argentia was determined using a method adapted from Abayo et al. (1997). The test plants were grown in pots filled with sand for 14 days in the screen house. Eight months old Striga hermonthica seeds were surface sterilised in the laboratory for $5 \mathrm{~min}$ using $1 \%$ sodium hypochlorite solution and washed with distilled water. The seeds were then conditioned by soaking in $30 \mathrm{ml}$ distilled water and incubated in the dark at $28^{\circ} \mathrm{C}$ for 14 days. After 14 days, the test plants were gently up rooted, their roots washed with distilled water and cut into $1 \mathrm{~cm}$ lengths.

Two moistened regular filter papers were placed in each of six petridishes of $9 \mathrm{~cm}$ diameter. An aluminium foil ring of $1 \mathrm{~cm}$ diameter and $1.5 \mathrm{~cm}$ height was placed in the centre of each petridish. One gram of root pieces of test plants were placed in the centres of the aluminium foil rings. Each petridish contained one test 
plant with the sixth petridish treated with only distilled water. Discs of regular filter paper, $6 \mathrm{~mm}$ in diameter, containing 30-40 conditioned seeds of $S$. hermonthica each, were placed around each ring in four rows running perpendicular to the ring to form a cross. Each row contained three discs placed edge to edge with the first disc touching the edge of the ring. This was to account for distance away from the stimulant source. The disc closest to the central ring was considered as "distance 1 ", the second as "distance 2" and the third as "distance 3" (Abayo et al., 1997). Since each disk was $6 \mathrm{~mm}$ in diameter, distances 1-3 were taken to be from the edge of the centre ring to the middle of each disc, i.e., 3, 9 and $15 \mathrm{~mm}$ respectively.

Since these distances were equidistant, the degree of germination was to be an indication of the amount of germination stimulant produced by the test plant. The distances were therefore also independent variates just as the different crops and replications. The rows were treated as replicates. Three millilitres of distilled water was added to the roots in each ring. Distilled water was considered to be the negative control while the susceptible sorghum variety was considered to be the positive control. The petridishes were covered and kept in the dark at room temperature for $48 \mathrm{~h}$. After $48 \mathrm{~h}$ the discs were taken out so as to count germinated Striga seeds under a microscope at low power $(\times 16$ magnification). The germinated seeds out of the total number of seeds in each disk were counted. Percent germination induced by each crop at each distance was computed.

Table 1

The effect of inter-planting Celosia argentia and cowpea into sorghum on Striga emergence

\begin{tabular}{lcccc}
\hline Treatment & \multicolumn{4}{c}{ Striga emergence $^{\mathrm{a}}\left(\mathrm{plants} / \mathrm{m}^{2}\right)$} \\
\cline { 2 - 5 } & $1999 \mathrm{a}$ & $1999 \mathrm{~b}$ & $2000 \mathrm{a}$ & Mean \\
\hline Cowpea/sorghum & $8.6^{\mathrm{b}}$ & $4.4^{\mathrm{b}}$ & $33.0^{\mathrm{b}}$ & 15.3 \\
C. argentia/sorghum & $13.5^{\mathrm{b}}$ & $7.1^{\mathrm{b}}$ & $34.4^{\mathrm{b}}$ & 18.3 \\
Sorghum(sole) & $24.6^{\mathrm{b}}$ & 21.1 & 76.7 & 40.8 \\
C.V. $(\%)$ & 26.3 & 12 & 6.1 & \\
\hline
\end{tabular}

${ }^{a}$ Analysis based on transformed data. Means presented as original data.

${ }^{\mathrm{b}}$ Significantly low, L.S.D. $(5 \%)$.

\subsection{Data analysis}

Data for all the three experiments described above were analysed using Genstat 5 release 3.2 statistical package.

\section{Results and discussion}

\subsection{Field experiment: the effect of inter-planting \\ C. argentia and cowpea into sorghum on Striga \\ emergence and growth and yield of sorghum}

Inter-planting $C$. argentia and cowpea into sorghum consistently reduced Striga emergence compared to where sorghum was planted alone for all the three seasons of this study (Table 1). The difference in Striga suppression between cowpea and $C$. argentia was not significant in all the seasons but cowpea suppressed Striga slightly more than $C$. argentia. $C$. argentia reduced Striga emergence by an average of $55 \%$ in a season compared to the sole sorghum treatment. The effect of cowpea in suppressing Striga had earlier been reported (Ariga et al., 1997a; Obilana and Ramaiah, 1992). These inter-crops reduce Striga emergence by inducing suicidal germination of Striga seeds. Cowpea, being a leguminous crop, additionally fixes nitrogen into the soil, which further suppresses Striga development.

The early growth stages of sorghum i.e. time of flowering and plant height at flowering were not significantly affected by the different treatments in all the three seasons of this study (data not shown). This shows that inter-planting sorghum with $C$. argentia or cowpea has no effect on the early growth stages of sorghum. However, the later growth stages of sorghum (heading and grain yield) were clearly affected by the treatments (Table 2). The number of harvestable heads per plot was significantly affected by inter-planting particularly during the first rains of 2000. Inter-planting $C$. argentia into sorghum gave a significantly higher number of sorghum heads per plot compared to the other treatments. Sorghum grain yields were generally lower than expected particularly in the second rains of 1999 and first rains of 2000. This was due to low rainfall and pests and diseases. In the second rains of 1999, the

Table 2

The effect of inter-planting Celosia argentia and cowpea into sorghum on sorghum yield

\begin{tabular}{|c|c|c|c|c|c|c|c|c|}
\hline \multirow[t]{2}{*}{ Treatment } & \multicolumn{4}{|c|}{ No. heads per plot } & \multicolumn{4}{|c|}{ Grain yield (kg/ha) } \\
\hline & $1999 a$ & $1999 b$ & $2000 \mathrm{a}$ & Mean & $1999 a$ & $1999 b$ & $2000 \mathrm{a}$ & Mean \\
\hline Cowpea/sorghum & 268.8 & 223 & 151 & 214.3 & 413 & 163 & 134 & 236.7 \\
\hline C. argentia/sorghum & 294 & 224 & 229 & 249 & 697 & 186 & 168 & 350.3 \\
\hline Sorghum(sole) & 294 & 174 & 119 & 195.7 & 674 & 153 & 93 & 306.7 \\
\hline s.e.d & 19.3 & 30.3 & 26.4 & & 102.5 & 46.2 & 30.1 & \\
\hline C.V. $(\%)$ & 10.7 & 44.6 & 33.7 & & 31.6 & 82.3 & 48.4 & \\
\hline
\end{tabular}


average rainfall during the growing period was $87 \mathrm{~mm}$ and in the first rains of 2000 it was $96.5 \mathrm{~mm}$. No measure was taken to control pests and diseases.

However, inter-planting $C$. argentia into sorghum maintained higher sorghum grain yield than other treatments in all the three seasons of the study. In the first rains of 1999, inter-planting cowpea into sorghum resulted in the lowest sorghum grain yield. This is because cowpea grew much vigorously and exerted greater competition on sorghum. During the second rains, 1999 and first rains, 2000, the sole sorghum treatment gave the lowest yield. Cowpea did not exert much competition because the amount of rainfall was so low to enable it grow vigorously.

\subsection{The screen house experiment}

\subsubsection{The effect of different sorghum: $C$. argentia} inter-planting ratios on Striga emergence

Striga emergence was influenced by the different sorghum: $C$. argentia inter-planting ratios (Table 3). The lowest emergence value of three Striga plants/pot was

Table 3

The effect of different proportions of sorghum and $C$. argentia on Striga emergence $^{\mathrm{a}}$

\begin{tabular}{llccc}
\hline Sorghum/C. argentia ratio & \multicolumn{4}{l}{ Striga emergence (plants/pot) } \\
\cline { 2 - 5 } & \multicolumn{3}{l}{ Weeks after crop emergence } \\
& 5 & 7 & 9 & Mean \\
\hline $1: 1$ & 4 & 12 & 12 & 9 \\
$2: 1$ & 6 & 13 & 12 & 10 \\
$3: 1$ & 7 & 13 & 12 & 11 \\
$1: 2$ & 1 & 6 & 7 & 5 \\
$1: 3$ & 1 & 4 & 4 & 3 \\
$1: 0$ & 3 & 12 & 12 & 9 \\
C.V. $(\%)$ & 7.5 & 14 & 16 & \\
\hline
\end{tabular}

${ }^{a}$ Analysis based on transformed data. Means presented as original data. L.S.D (5\%) not significant. recorded where the proportion of $C$. argentia was high i.e. 1:3 and the highest value of 11 Striga plants/pot was recorded in the treatment where $C$. argentia was lowest i.e. $3: 1$. In general, the number of Striga plants that emerged increased with time with the lowest being recorded at 5 weeks after emergence of sorghum. The results show that increasing the population of $C$. argentia relative to sorghum suppresses Striga.

\subsubsection{The effect of different sorghum: $C$. argentia inter-} planting ratios on the growth and yield of sorghum

All growth and yield parameters of sorghum were influenced by both Striga infestation and inter-planting ratio (Table 4).

\subsection{Sorghum flowering}

In the pots infested with Striga, sorghum failed to flower for most of the inter-planting ratios except for the 1:1 and 1:2 sorghum:C. argentia inter-planting ratios. These flowered 12 and 16 days late compared to the same ratios that were not infested with Striga respectively. There were no significant differences in flowering among the non-infested treatments.

\subsection{Plant height}

Sorghum plant height was significantly affected by the different treatments. The treatments infested with Striga had significantly shorter sorghum plants compared to the non-infested treatments. Among the infested treatments, the $1: 2$ and $1: 1$ sorghum: $C$. argentia interplanting ratios had significantly taller sorghum plants particularly when compared with the 2:1 and 3:1 interplanting ratios. There were no significant differences in sorghum height between the different inter-planting ratios under non-Striga infestation.

Table 4

The effect of different proportions of sorghum and C. argentia on the growth and yield of sorghum under Striga infestation and non-Striga infestation

\begin{tabular}{|c|c|c|c|c|c|c|c|c|c|c|}
\hline \multirow[t]{2}{*}{ Sorghum $/$ C. argentia ratio } & \multicolumn{5}{|c|}{ Infested pots } & \multicolumn{5}{|c|}{ Non-infested pots } \\
\hline & $\begin{array}{l}\text { Days to } \\
\text { flower }\end{array}$ & $\begin{array}{l}\text { Plant } \\
\text { height } \\
(\mathrm{cm})\end{array}$ & $\begin{array}{l}\text { Dry matter } \\
\text { per plant } \\
\text { (g) }\end{array}$ & $\begin{array}{l}\text { Grain yield } \\
\text { per plant } \\
\text { (g) }\end{array}$ & $\begin{array}{l}\text { Grain } \\
\text { yield } \\
(\mathrm{kg} / \mathrm{ha})\end{array}$ & $\begin{array}{l}\text { Days to } \\
\text { flower }\end{array}$ & $\begin{array}{l}\text { Plant } \\
\text { height } \\
(\mathrm{cm})\end{array}$ & $\begin{array}{l}\text { Dry matter } \\
\text { per plant } \\
\text { (g) }\end{array}$ & $\begin{array}{l}\text { Grain yield } \\
\text { per plant } \\
\text { (g) }\end{array}$ & $\begin{array}{l}\text { Grain } \\
\text { yield } \\
(\mathrm{kg} / \mathrm{ha})\end{array}$ \\
\hline $1: 1$ & 96 & 73.7 & 7.4 & 1.12 & 269.6 & 84.0 & 157.7 & 25.3 & 9.9 & 2382.7 \\
\hline $2: 1$ & - & 25.8 & 2.9 & 0.0 & 0.0 & 85.8 & 132.3 & 15.0 & 3.8 & 914.6 \\
\hline $3: 1$ & - & 25.0 & 2.2 & 0.0 & 0.0 & 85.0 & 125.7 & 15.0 & 3.8 & 914.6 \\
\hline $1: 2$ & 93 & 80.0 & 8.8 & 1.5 & 361.0 & 77.3 & 146.0 & 25.0 & 8.9 & 2141.9 \\
\hline $1: 3$ & - & 38.4 & 4.4 & 0.0 & 0.0 & 80.7 & 158.0 & 26.4 & 6.7 & 1612.9 \\
\hline $1: 0$ & - & 42.7 & 8.9 & 0.0 & 0.0 & 81.0 & 146.3 & 30.4 & 9.3 & 2238.3 \\
\hline Mean & 94.5 & 47.6 & 5.8 & 0.44 & 105.1 & 82.3 & 144.3 & 22.9 & 7.1 & 1700.8 \\
\hline s.e.d & 2.9 & 22.6 & 1.4 & 2.3 & 56.2 & & & & & \\
\hline C.V. $(\%)$ & 4.3 & 34.3 & 30.1 & 40.3 & 58.6 & & & & & \\
\hline
\end{tabular}

- Did not flower at all. 


\subsection{Dry matter}

The differences in dry matter per plant of sorghum were significant between the different treatments. The treatments under Striga infestation had significantly low dry matter per plant of sorghum compared to those without Striga infestation. Among the treatments under Striga infestation, the 1:2, 1:1 and 1:0 sorghum: $C$. argentia inter-planting ratios had significantly high dry matter per plant of sorghum compared to the other ratios. For the treatments without Striga infestation, 2:1 and 3:1 sorghum:C argentia inter-planting ratios gave significantly lower dry matter per plant of sorghum compared to the other ratios.

\subsection{Grain yield}

As in flowering, sorghum failed to produce grain in infested treatments for most of the sorghum: $C$. argentia inter-planting ratios except for the 1:2 and 1:1 ratios. Under Striga infestation, 1:2 sorghum:C. argentia interplanting ratio gave a higher grain yield both per plant and in $\mathrm{kg} /$ ha than the $1: 1$ ratio. In treatments without Striga infestation, 1:1, 1:2 and 1:0 sorghum:C argentia inter-planting ratios resulted in higher grain yields per plant than 2:1, 3:1 and 1:3 ratios. Considering grain yield in $\mathrm{kg} / \mathrm{ha}, 1: 1$ and 1:2 sorghum: $C$. argentia interplanting ratios had higher sorghum grain yields despite having low sorghum populations compared to other treatments like 2:1 and 3:1 inter-planting ratios.

Basing on Striga emergence, sorghum plant height, sorghum dry matter per plant and sorghum grain yield, the appropriate sorghum:C. argentia inter-planting ratio, which can effectively suppress Striga and maintain increased sorghum yield is 1:2.

\subsection{The laboratory experiment: the influence of C. argentia on Striga seed germination}

C. argentia and all other crops tested stimulated Striga seed germination (Table 5). The crops differed significantly in their abilities to stimulate Striga seed germination. The susceptible sorghum variety stimulated Striga germination much more than all other crops and was closely followed by cotton though the difference between the two was not significant. The capacity of cotton and other trap crops to stimulate Striga seed germination has been reported (Abayo et al., 1997; Ariga et al., 1997b). However, no information has been reported for $C$. argentia.

In this study, it has been demonstrated that $C$. argentia can also induce Striga seeds to germinate. It is suggested that the differences in percent germination of Striga seeds induced by different crops is due to different amounts of germination stimulant produced.
Table 5

Percent Striga seed germination as induced by $C$. argentia and selected trap crops

\begin{tabular}{lcclr}
\hline Crop/plant & \multicolumn{3}{l}{ \% germination of Striga seeds } & \\
\cline { 2 - 5 } & $\begin{array}{l}\text { Distance 1 } \\
(3 \mathrm{~mm})\end{array}$ & $\begin{array}{l}\text { Distance } 2 \\
(9 \mathrm{~mm})\end{array}$ & $\begin{array}{l}\text { Distance 3 } \\
(15 \mathrm{~nm})\end{array}$ & Mean \\
\hline C. argentia & 1.48 & 2.58 & 5.67 & 3.24 \\
$\begin{array}{l}\text { Cotton (BPA 97) } \\
\text { Cowpea (Ebelat) }\end{array}$ & 14.48 & 11.4 & 4.6 & 10.16 \\
$\begin{array}{l}\text { Seredo (improved } \\
\text { sorghum) }\end{array}$ & 5.33 & 0.85 & 0.93 & 0.71 \\
$\begin{array}{l}\text { Inoke } \\
\text { (susceptible }\end{array}$ & 15.25 & 6.78 & 5.65 & 5.92 \\
$\begin{array}{l}\text { sorghum) } \\
\text { (positive control) }\end{array}$ & & 9.33 & 7.55 & 10.71 \\
$\begin{array}{l}\text { Distilled water } \\
\text { (negative control) }\end{array}$ & 0.0 & 0.0 & 0.0 & \\
& & & & \\
Mean & 6.15 & 5.16 & 4.07 & \\
s.e.d & 1.5 & & & \\
s.e.d & 1.7 & & & \\
C.V. (\%) & 60 & & & \\
\hline
\end{tabular}

${ }^{\text {a }}$ Differences between treatments/crops.

${ }^{\mathrm{b}}$ Differences between distances.

Crops which stimulated more Striga seeds to germinate possibly, produced more germination stimulant. The differences in percent germination of Striga seeds between the three distances away from stimulant source was not significant. However, for most crops, the percentage seemed to decrease with distance while for $C$. argentia and cowpea, it seemed to increase with distance. This possibly suggests the presence of germination inhibitors in $C$. argentia and cowpea root exudes such that dilution away from the stimulant source seemed to change the balance in favour of germination stimulants. The germination stimulants in cotton, cowpea and sorghum have been isolated and reported (Hauck et al., 1992; Muller et al., 1992). This has not been done for $C$. argentia. It is necessary that the germination stimulant produced by $C$. argentia also be isolated and characterised.

\section{Conclusions}

Celosia argentia reduces Striga emergence on sorghum by $55 \%$ and increases the yield of a susceptible sorghum variety by $35 \%$ in the field. The use of Celosia argentia in Striga control would result in increased sorghum productivity without a matching increase in cost of production. The appropriate inter-planting ratio between sorghum and Celosia argentia is 1:2, respectively. Celosia argentia can induce suicidal germination of Striga seeds; therefore, it can be used in short-term fallows to reduce Striga seed numbers in the soil. 


\section{Acknowledgements}

We thank the IPM CRSP for funding this research and the farmers of Kumi district who provided land and participated in the field experiments.

\section{References}

Abayo, G.O., Oswald, A., Ransom, J.K., Ariga, E.S., 1997. Stimulation of Striga hermonthica germination by plant species indigenous to Eastern Africa. In: Adipala, E., Tusiime, G., Okori, P. (Eds.), Proceedings of the 16th Biennial Weed Science Society Conference for Eastern Africa. WSSEA, Kampala, pp. 231-240.

Anonymous, 1997. Striga survey in Eastern Uganda. Serere Agricultural and Animal production Research Institute/National Agricultural Research Organisation.

Ariga, E.S., Berner, D.K., Chweya, J., 1997a. Effects of cowpea and its residues on parasitism of Striga hermonthica on maize. In: Adipala, E., Tenywa, J.S., Ogenga-Latigo, M.W. (Eds.), African Crop Science Conference Proceedings, Vol. 3, pp. 877-885.

Ariga, E.S., Ransom, J.K., Odhiambo, G.D., Abayo, G., Ndungu, D.K., 1997b. Potential of using cotton and other trap crops for Striga hermonthica management in cereals in Kenya. In: Proceed- ings of the 16th Biennial Weed Science Society Conference for Eastern Africa. WSSEA, Kampala, pp. 247-254.

Busari, L.D., Misari, S.M., Olaniyan, G.O., Indarubu, A.A., 1997. Weed management systems in chewing cane production in the inland valleys of Nigeria. In: Adipala. E., Tusiime, G., Okori, P. (Eds.), Proceedings of the 16th Biennial Weed Science Society Conference for Eastern Africa. WSSEA, Kampala, pp. 97-102.

Department of Lands and Survey, 1967. Map of Uganda, 156pp.

Hauck, C., Muller, S., Shildknecht, H., 1992. A germination stimulant for parasitic flowering plants from Sorghum bicolor, a genuine host plant. J. Plant Physiol. 139, 474-478.

Muller, S., Hauck, C., Schildknecht, H., 1992. Germination stimulants produced by Vigna unguiculata (Walp.) cv Saunders, Upright. J. Plant Growth Regulat. 11, 77-84.

Obilana, A.T., Ramaiah, K.V., 1992. Striga (witchweeds) in sorghum and Millet: knowledge and future research needs. In: deMilliano, W.A.J., Frederikson, R.A., Bengston, G.D. (Eds.), Sorghum and Millet Diseases, A Second World Review. ICRISAT, pp. 187-207.

Sauerborn, J., 1991. The economic importance of the phytoparasites Orobanche and Striga. In: Ransom, J.K., Musselman, L.J., Worsham, A.D., Parker, C. (Eds.), Proceedings of the 5th International Symposium on Parasitic Weeds. CIMMYT, Nairobi, pp. 137-143.

Webb, M., Conroy, C., Baguma, D., Kabanyoro, R., 1993. Survey of the socio-economics of weed control on smallholder farms in three districts of Uganda. Report R2014(S), Natural Resources Institute, Chatham, UK, 26pp. 